\title{
Risk Factors for the Spread of Parasitic Zoonoses among Domestic Cat Owners and Their Families in Rural Areas
}

\author{
Witold Kołłątaj $^{1}$, Barbara Kołłątaj ${ }^{2}$, Irena Dorota Karwat ${ }^{2}$, Marian Sygit ${ }^{3,4} \&$ Katarzyna Sygit $^{3}$ \\ ${ }^{1}$ III Chair of Paediatrics, Department of Paediatric Endocrinology \& Diabetology, Medical University of Lublin, \\ Poland \\ ${ }^{2}$ Chair and Department of Epidemiology, Medical University of Lublin, Poland \\ ${ }^{3}$ Department of Health Education, University of Szczecin, Poland \\ ${ }^{4}$ Institute of Rural Health in Lublin, Poland \\ Correspondence: Witold Kołłątaj, III Chair of Paediatrics, Department of Paediatric Endocrinology \& \\ Diabetology, Medical University of Lublin, Chodźki 2, Lublin 20-093, Poland. Tel: 48-81-718-5440. E-mail: \\ w.kollataj@umlub.pl
}

Received: February 29, 2012 Accepted: March 25, 2012 Online Published: June 20, 2012

doi:10.5539/ep.v1n2p148 URL: http://dx.doi.org/10.5539/ep.v1n2p148

\begin{abstract}
The close animal - human contacts are risky for people especially in cases of any negligence towards proper veterinary care, deworming and vaccination procedures as well as human and cat hygiene. Among possible risks there are parasitic zoonoses threats.

The study involved 146 cat owners from selected rural areas in Lublin province. Altogether they possessed 309 cats.

A special original inquiry questionnaire was used.

The survey was carried out during the period: January 2011- May 2011. Most of polled (84.9\%) have reported deworming procedure negligence, $60.4 \%$ of polled have never bathed their cats, only $63.7 \%$ of cat owners have declared separations of humans' and cats' sleeping places, $65.1 \%$ of owners have declared no any restrictions concerning cats' movement around both wild environment and children's places for fun and recreation.

Conclusions: In rural areas, hygiene and veterinary cats care negligence as well as animal - human coexistence conditions may increase the risk of zoonotic parasite diseases spreading.
\end{abstract}

Keywords: rural areas, cats, parasitosis, zoonosis, risk

\section{Introduction}

Among the tens of thousands of species described in Central Europe, almost 1/4 of them are parasites. Several dozen of them may affect people, nearly 40 - may live inside the human body, many of such species are parasites posing threats both to humans and domesticated animals including domestic cats. In our country, in most cases, human parasite infestations are asymptomatic. But it doesn't mean that the problem of parasitic zoonoses is trivial.

Arthropods (Sarcoptes scabiei, Pulex irritans, Ctenocephalides felis) may cause appearance of various difficult to manage cutaneous symptoms, including blistering and contact dermatitis, neuro-cutaneous syndrome (NCS), allergic reaction and secondary infections (Amen, 2001). Pulex irritans and Ctenocephalides felis may be vectors for Dipylidium caninum and such zoonoses as: tularemia, antrax and Lyme borreliosis (Randolph, 2001; Stojčević, Sušić, \& Lučinger, 2010).

Internal parasites pose even life-threatening medical problems to babies and young children, pregnant woman and their foetuses, undernourished patients as well as to individuals with different kinds of immune system deficiencies: primary immunodeficiency being an inborn problem and acquired immunodeficiency (Barsoum, 2007; Bojar, \& Szymańska, 2010; Büyükbaba Boral, Uysal, Alan, \& Nazlican, 2004; Kołłątaj, Niewiadomy, \& Szewczyk, 2001; Niedworok, \& Płaneta-Małecka, 2004; Smith et al., 1998; Valar et al., 2007).

The number of people with acquired immunodeficiency still increases. Among them there are those with immune 
system problems caused by malnutrition, aging, particular medications (chemotherapy agents, disease-modifying antirheumatic drugs as well as immunosuppressive drugs chronically used by organ recipients after organ transplants) and by specific diseases directly or indirectly impairing the immune system (some types of cancer, particularly those of the bone marrow and blood cells, diseases causing malnutrition and certain infections such as infection with the human immunodeficiency virus - HIV).

The close animal - human contacts are risky for people especially in cases of any negligence towards proper veterinary care, deworming and vaccination procedures as well as human and cat hygiene. Among possible risks there are parasitic zoonoses threats.

Because of the fact that most of zoonotic transmissions are effects of improper animals' hygiene and vet care as well as improper human hygiene, people should follow listed beneath simple tips to prevent passing parasites from cats to humans (Stull, Carr, Chomel, Berghaus, \& Hird, 2007; Schantz, 2003; Wolfe \& Wright, 2003; Guillot \& Bouree, 2007; Grant \& Olsen, 1999):

1st. Practicing good personal hygiene;

2nd. Practising proper food hygiene (some parasite zoonoses are transmitted by the waterborne or foodborne routes);

3rd. Controlling pet parasite infections through internal and external parasite treatment and control (necessary help of veterinary doctors);

4rd. Minimizing exposure of children, pregnant women and immunocompromised people to potentially contaminated environments;

5th. Cleaning up pet faces regularly to reduce environmental contamination with infective parasite stages;

6th. Minimizing contacts of cats with wild animals and contaminated environment;

7th. Discussing pet ownership with family physicians or specialists (concerns immunocompromised potential cat owners).

Although listed above tips seem to be obvious and simple to keep, the practice of everyday life seems to indicate that such hygiene recommendations are often neglected. Because of a specific condition of life and socio-cultural identity, such negligence seems to be probable.

The precise determination of the real scale of such types of negligence and cat breeding mistakes is necessary to take the proper action against zoonoses spreading.

\section{Aim}

The aim of this study was to determine real scale of cats care negligence and breeding mistakes favouring the spread of parasitic zoonotic diseases in rural areas of selected districts of Lublin Province.

\section{Material and Methods}

\subsection{Material}

The study involved 146 cat owners from rural areas of Bełżyce, Chodel, Opole Lubelskie and Poniatowa districts in Lublin province.

The population of these districts has 53910 people, including 28692 ones - the inhabitants of rural areas (Główny Urząd Statystyczny [GUS], 2011). The study involved the group, which represented only those residents who were inhabitants of rural areas.

In the rural areas within these districts, there are 110 population centers - villages.

There was performed randomly selection of 29 villages located in the described areas (seven in each: Bełżyce and Chodel districts, six in the Poniatowa district and nine in the district of Opole Lubelskie - that is proportionally to the rural populations living in mentioned districts). Then six representatives in each randomly selected village were asked to fill out prepared questionnaires.

The representatives being surveyed were cat owners:

-individuals who because of their health status problems were patients of the Outpatient Clinics in Poniatowa (Lublin province, Poland).

- their close neighbors.

Such method of selection of respondents was due to the fact that these rural areas have low population densities (it creates difficulties with access to places of residence of the potential respondents) as well as the fact that 
people living in rural areas are reluctant to accept the interviewers in their houses and usually refuse to fill in questionnaires delivered by post (this conclusion is based on prior experiences that authors have had with people living there).

The surveyed owners represented both the purebred and not purebred cat owners who possessed cats for pleasure and companionship (pets), as well as for farming purposes (to protect farms from rodents).

Altogether they possessed 309 cats.

\subsection{Method of Data Collection}

A special original inquiry questionnaire with questions concerning details of residence, education and professional status of cat owners, aspects of cats breeding such as hygiene (frequency of bathing), veterinary care, veterinary health certificate possession, frequency of deworming procedures and aspects of animal humans coexistence as well as cats freedom of movement around the house and the surrounding area was applied.

The survey has been carried out during the period: January 2011- July 2011 and has been based on survey feedback issued during visit in the outpatient clinics and received during subsequent visits to clinics.

The described above method of selection and questionnaires distribution based on the involvement of people being held in high esteem (clinic doctors) brought beneficial effect on respondents' reactions and on high percentage of returned questionnaires.

The percentage of returned questionnaires was equal to $84 \%$.

\subsection{Data Presentation}

All obtained data were present in tables - both as absolute values and percentages.

\section{Results}

The obtained data are presented below as tables (Tables 1-5).

Such data present the prevalence of negligence in the care and breeding of cats that have the effect of increasing the risk of spreading parasitic zoonoses.

\subsection{Possible Occasional Cats'Access to Places for Children's Fun and Recreation}

Transmission of zoonoses is more possible when human - animal coexistence is too close or when people neglect good personal hygiene. It is obvious that children are particularly vulnerable to zoonoses transmission due to their natural tendencies to unhealthy behaviours, especially during play and eating. Cats, their excrements and pelage may be vectors of many zoonoses and pose a potential threat to children.

Unrestricted cats' movement around the unfenced areas (wild environment) increases the risk of contacts with sources of parasitic infections. Unlimited these cats access to people, including their places of rest, fun and sleep may create opportunities for zoonotic transmission.

The most dangerous cats - human coexistence conditions may be described as (Table 1):

$1^{\text {st }}$. unrestricted cats' movement (rows "Not restricted but mainly living quarters" and "Not restricted but mainly outside living quarters") and their access to playgrounds, children's places for fun and recreation or only to places for fun. Such options were checked by 80 polled, that mean $54.8 \%$ of surveyed cat owners.

$2^{\text {nd }}$. free movement restricted to areas outside living quarters (row "Areas outside living quarters ") and possible access to places for children's fun and recreation (column "unrestricted") or to places for children's fun (with or without supervision of adults) - 15 cases, that means $10.3 \%$ of surveyed.

Both of them concern $65.1 \%$ of all cat owners' households in rural regions.

Only 29 owners referred two, the most safe cats-people-environment relations - i.e.:

$1^{\text {st }}$. cats not allowed to free move outside living quarters (free movement restricted to living quarters): 17 respondents ( $11.6 \%$ of polled) or

$2^{\text {nd }}$. lack of consent to the presence of cats in residential areas or playgrounds (column "No any"; 37 respondents - that means $25.3 \%$ of polled).

\subsection{Possible Occasional Access of Cats to Kitchens, Larders, Dining Rooms and Bedrooms}

Potentially very dangerous to humans may be the presence of cats in areas of storage and processing of food, dining rooms as well as bedrooms. Unrestricted cats' access to such places makes possible to pollute food, tables, 
plates and beddings with invasive (for humans) forms of parasites. The risk of such danger is described by data presented in Table 2.

Total separations of cats and areas connected with storing and preparing food for humans as well as places for eating and sleeping were declared only by 35 owners (39.7\%) - Table 2 (column "No any or eventually to halls and porches"). The rest of polled (60.3\%) checked answers suggesting more or less risky contacts. Among them 72 owners $(49.2 \%)$ used to allow their cats to visit kitchens, larders, dining rooms as well as bedrooms (column "Unrestricted").

Table 1. Possible occasional cats' access to places for children's fun and recreation

\begin{tabular}{|c|c|c|c|c|c|c|c|c|c|c|}
\hline \multirow{4}{*}{$\begin{array}{l}\text { Free movement restricted } \\
\text { to: }\end{array}$} & \multicolumn{10}{|c|}{$\begin{array}{l}\text { Possible occasional cats' access to places for children's fun and } \\
\text { recreation }\end{array}$} \\
\hline & \multirow{2}{*}{\multicolumn{2}{|c|}{$\begin{array}{l}\text { Unrestrict } \\
\text { ed }\end{array}$}} & \multicolumn{4}{|c|}{ Access limited to: } & \multirow{2}{*}{\multicolumn{2}{|c|}{ No any }} & \multirow{2}{*}{\multicolumn{2}{|c|}{ Total }} \\
\hline & & & \multicolumn{2}{|c|}{$\begin{array}{l}\text { places for } \\
\text { children's fun; no } \\
\text { any supervision } \\
\text { of adults }\end{array}$} & \multicolumn{2}{|c|}{$\begin{array}{l}\text { places for } \\
\text { children's fun; } \\
\text { access supervised } \\
\text { by adults }\end{array}$} & & & & \\
\hline & $\mathrm{n}$ & $\%$ & $\mathrm{n}$ & $\%$ & $\mathrm{n}$ & $\%$ & $\mathrm{n}$ & $\%$ & $\mathrm{n}$ & $\%$ \\
\hline Only living quarters & 0 & 0.0 & 7 & 4.8 & 5 & 3.4 & 5 & 3.4 & 17 & 11.6 \\
\hline $\begin{array}{l}\text { Not restricted but mainly } \\
\text { living quarters }\end{array}$ & 5 & 3.4 & 3 & 2.1 & 29 & 19.9 & 12 & 8.2 & 49 & 33.6 \\
\hline $\begin{array}{l}\text { Not restricted but mainly } \\
\text { outside living quarters }\end{array}$ & 20 & 13.7 & 0 & 0.0 & 24 & 16.4 & 0 & 0.0 & 44 & 30.1 \\
\hline $\begin{array}{l}\text { Areas outside living } \\
\text { quarters }\end{array}$ & 5 & 3.4 & 0 & 0.0 & 10 & 6.8 & 21 & 13.7 & 36 & 24.7 \\
\hline Total & 30 & 20.5 & 10 & 6.9 & 68 & 46.6 & 38 & 26.0 & 146 & 100.0 \\
\hline
\end{tabular}

Table 2. Possible occasional access of cats to kitchens, larders, dining rooms and bedrooms

\begin{tabular}{|c|c|c|c|c|c|c|c|c|c|c|c|c|}
\hline \multirow{4}{*}{$\begin{array}{l}\text { Free } \\
\text { restricted to: }\end{array}$} & \multicolumn{10}{|c|}{ Possible access to kitchens, larders, dining rooms and bedrooms } & & \\
\hline & \multirow{2}{*}{\multicolumn{2}{|c|}{ Unrestricted }} & \multicolumn{6}{|c|}{ Access limited to: } & \multirow{2}{*}{\multicolumn{2}{|c|}{$\begin{array}{l}\text { No any or } \\
\text { eventually to } \\
\text { halls and } \\
\text { porches }\end{array}$}} & \multirow{2}{*}{\multicolumn{2}{|c|}{ Total }} \\
\hline & & & \multicolumn{2}{|c|}{$\begin{array}{l}\text { kitchens } \\
\text { and/or } \\
\text { larders }\end{array}$} & \multicolumn{2}{|c|}{$\begin{array}{l}\text { dining } \\
\text { rooms }\end{array}$} & \multicolumn{2}{|c|}{ bedrooms } & & & & \\
\hline & $\mathrm{n}$ & $\%$ & $\mathrm{n}$ & $\%$ & $\mathrm{n}$ & $\%$ & $\mathrm{n}$ & $\%$ & $\mathrm{n}$ & $\%$ & $\mathrm{n}$ & $\%$ \\
\hline Only living quarters & 12 & 8.2 & 0 & 0.0 & 0 & 0.0 & 0 & 0.0 & 5 & 3.4 & 17 & 11.6 \\
\hline $\begin{array}{l}\text { Not restricted but mainly } \\
\text { living quarters }\end{array}$ & 31 & 21.2 & 0 & 0.0 & 0 & 0.0 & 0 & 0.0 & 20 & 13.7 & 51 & 34.9 \\
\hline $\begin{array}{l}\text { Not restricted but mainly } \\
\text { outside living quarters }\end{array}$ & 24 & 16.4 & 0 & 0.0 & 5 & 3.4 & 0 & 0.0 & 15 & 10.3 & 44 & 30.1 \\
\hline $\begin{array}{l}\text { Areas outside living } \\
\text { quarters }\end{array}$ & 5 & 3.4 & 0 & 0.0 & 11 & 7.5 & 0 & 0.0 & 18 & 12.3 & 34 & 23.3 \\
\hline Total & 72 & 49.2 & 0 & 0.0 & 16 & 10.9 & 0 & 0.0 & 58 & 39.7 & 146 & 100.0 \\
\hline
\end{tabular}

\subsection{Sleeping Places for Cats}

No one of respondents checked the most risky combination: sleeping with a cat which is allowed complete unrestricted freedom of movement (Table 3). 93 cat owners (63.7\%) declared separations of humans' and cats' sleeping places (cats are not allowed to sleep inside living quarters). The rest -53 owners (36.3\%) checked other answers suggesting more or less risky contacts (Table 3); it may be interpreted as approval for 
their cats' possible contacts with every furniture, domestic appliances or clothing. 36 cat owners (24.4\%) declared that their cats were allowed to sleep in living quarters in not defined sleeping places, only 17 respondents (11.6\%) declared allowance to presence of cat beds in living quarters.

Table 3. Sleeping places for cats

\begin{tabular}{|c|c|c|c|c|c|c|c|c|c|c|}
\hline \multirow{4}{*}{ Free movement restricted to: } & \multicolumn{10}{|c|}{ Sleeping place for the cat } \\
\hline & \multirow{2}{*}{\multicolumn{2}{|c|}{$\begin{array}{l}\text { Outside the } \\
\text { living } \\
\text { quarters }\end{array}$}} & \multicolumn{6}{|c|}{ Inside living quarters } & \multirow{2}{*}{\multicolumn{2}{|c|}{ Total }} \\
\hline & & & \multicolumn{2}{|c|}{$\begin{array}{l}\text { in a cat bed or } \\
\text { sleeping } \\
\text { place }\end{array}$} & \multicolumn{2}{|c|}{$\begin{array}{l}\text { in a not } \\
\text { defined place }\end{array}$} & \multicolumn{2}{|c|}{$\begin{array}{l}\text { with owners } \\
\text { or their } \\
\text { children }\end{array}$} & & \\
\hline & $\mathrm{n}$ & $\%$ & $\mathrm{n}$ & $\%$ & $\mathrm{n}$ & $\%$ & $\mathrm{n}$ & $\%$ & $\mathrm{n}$ & $\%$ \\
\hline Only living quarters & 0 & 0.0 & 12 & 8.1 & 5 & 3.5 & 0 & 0.0 & 17 & 11.6 \\
\hline $\begin{array}{l}\text { Not restricted but mainly } \\
\text { living quarters }\end{array}$ & 20 & 13.7 & 5 & 3.5 & 24 & 16.3 & 0 & 0.0 & 49 & 33.6 \\
\hline $\begin{array}{l}\text { Not restricted but mainly } \\
\text { outside living quarters }\end{array}$ & 37 & 25.3 & 0 & 0.0 & 7 & 4.7 & 0 & 0.0 & 44 & 30.1 \\
\hline Areas outside living quarters & 36 & 24.7 & 0 & 0.0 & 0 & 0.0 & 0 & 0.0 & 36 & 24.7 \\
\hline Total & 93 & 63.7 & 17 & 11.6 & 36 & 24.4 & 0 & 0.0 & 146 & 100.0 \\
\hline
\end{tabular}

4.4 Attitudes of the Owners towards Bathing, their Cats and Restrictions Concerning Free Movements of Cats

Instead of the fact that animals as well as people need hygienic procedures to enjoy good health, the idea of bathing cats gives rise to controversy. Such diversity of opinions present data placed in Table 4.

The most popular response to the question concerning the frequency of bathing cats was: "never" - 88 owners ( $60.4 \%$ of polled). 36 respondents $(24.7 \%)$ checked the option "Irregularly or less frequently than every 3 months". The option "Every 3 months or more frequently" was checked by nobody, the rest of polled (22 owners - that is $15.1 \%$ ) checked answer "It has taken place only once" or option suggesting bathing in cases of any parasitic disease suspicions.

Table 4. Attitudes of the owners towards bathing their cats and restrictions concerning free movements of cats

\begin{tabular}{|c|c|c|c|c|c|c|c|c|c|c|c|c|}
\hline & \multicolumn{10}{|c|}{ The frequency of bathing } & \multicolumn{2}{|c|}{ Total } \\
\hline & \multicolumn{2}{|c|}{ Never } & \multicolumn{2}{|c|}{$\begin{array}{l}\text { It has } \\
\text { taken } \\
\text { place only } \\
\text { once }\end{array}$} & \multicolumn{2}{|c|}{$\begin{array}{l}\text { Irregularly } \\
\text { or less } \\
\text { frequently } \\
\text { than every } \\
3 \text { months }\end{array}$} & \multicolumn{2}{|c|}{\begin{tabular}{l}
\multicolumn{1}{c}{ Every } \\
3 months or \\
more \\
frequently
\end{tabular}} & \multicolumn{2}{|c|}{$\begin{array}{l}\text { Only when } \\
\text { the owner } \\
\text { suspects a } \\
\text { parasitic } \\
\text { disease }\end{array}$} & & \\
\hline & $\mathrm{n}$ & $\%$ & $\mathrm{n}$ & $\%$ & $\mathrm{n}$ & $\%$ & $\mathrm{n}$ & $\%$ & $\mathrm{n}$ & $\%$ & $\mathrm{n}$ & $\%$ \\
\hline Only living quarters & 10 & 7.0 & 0 & 0.0 & 7 & 4.8 & 0 & 0.0 & 0 & 0.0 & 17 & 11.6 \\
\hline $\begin{array}{l}\text { Not restricted but } \\
\text { mainly living quarters }\end{array}$ & 27 & 18.5 & 7 & 4.8 & 15 & 10.3 & 0 & 0.0 & 0 & 0.0 & 49 & 33.6 \\
\hline $\begin{array}{l}\text { Not restricted but } \\
\text { mainly outside living } \\
\text { quarters }\end{array}$ & 20 & 13.7 & 5 & 3.4 & 14 & 9.6 & 0 & 0.0 & 5 & 3.4 & 44 & 30.1 \\
\hline $\begin{array}{l}\text { Areas outside living } \\
\text { quarters }\end{array}$ & 31 & 21.2 & 5 & 3.4 & 0 & 0.0 & 0 & 0.0 & 0 & 0.0 & 36 & 24.7 \\
\hline Total & 88 & 60.4 & 17 & 11.6 & 36 & 24.7 & 0 & 0.0 & 5 & 3.4 & 146 & 100.0 \\
\hline
\end{tabular}




\subsection{Deworming Prevention and Treatment Procedures Applied to Cats with Different Free Movement Restrictions}

Deworming procedure (including preventive deworming) is one of the best ways to prevent the spread of parasites. Its effectiveness depends on frequency, regularity and specificity of used antiparasitic means.

The attitude of cat owners towards deworming prevention may be characterized by data presented in Table 5 .

Only 12 owners ( $15.1 \%$ of polled) declared deworming procedure performed more frequently than once a year. Most of polled (i.e. rest of polled - that means $84.9 \%$ of 146 owners) checked answers suggesting deworming procedure negligence (deworming, performed once a year, when preparing to vaccination procedures or realized less frequently than once a year). $9(6.0 \%)$ used to apply deworming procedures less frequently than once a year, $63(43.0 \%)$ once a year, 44 owners $(30.2 \%)$ only when any parasites were noticed by cat owners - Table 5. No one checked the option "Never".

Table 5. Deworming prevention and treatment procedures applied to cats with different free movement restrictions

\begin{tabular}{|c|c|c|c|c|c|c|c|c|c|c|c|c|}
\hline \multirow{3}{*}{$\begin{array}{l}\text { Free movement restricted } \\
\text { to: }\end{array}$} & \multicolumn{12}{|c|}{ Deworming } \\
\hline & \multicolumn{2}{|c|}{$\begin{array}{l}\text { Only when } \\
\text { the cat is } \\
\text { vaccinated }\end{array}$} & \multicolumn{2}{|c|}{$\begin{array}{l}\text { When the } \\
\text { owner sees } \\
\text { parasites }\end{array}$} & \multicolumn{2}{|c|}{ Once a year } & \multicolumn{2}{|c|}{$\begin{array}{l}\text { More } \\
\text { frequently } \\
\text { than once } \\
\text { a year }\end{array}$} & \multicolumn{2}{|c|}{$\begin{array}{l}\text { Less } \\
\text { frequently } \\
\text { than once } \\
\text { a year }\end{array}$} & \multicolumn{2}{|c|}{ Never } \\
\hline & $\mathrm{n}$ & $\%$ & $\mathrm{n}$ & $\%$ & $\mathrm{n}$ & $\%$ & $\mathrm{n}$ & $\%$ & $\mathrm{n}$ & $\%$ & $\mathrm{n}$ & $\%$ \\
\hline Only living quarters & 0 & 0.0 & 5 & 3.5 & 12 & 8.1 & 0 & 0.0 & 0 & 0.0 & 0 & 0.0 \\
\hline $\begin{array}{l}\text { Not restricted but mainly } \\
\text { living quarters }\end{array}$ & 3 & 2.3 & 5 & 3.5 & 20 & 14.0 & 12 & 8.1 & 9 & 5.8 & 0 & 0.0 \\
\hline $\begin{array}{l}\text { Not restricted but mainly } \\
\text { outside living quarters }\end{array}$ & 0 & 0.0 & 14 & 9.3 & 24 & 16.3 & 7 & 4.7 & 0 & 0.0 & 0 & 0.0 \\
\hline $\begin{array}{l}\text { Areas outside living } \\
\text { quarters }\end{array}$ & 5 & 3.5 & 20 & 14.0 & 7 & 4.7 & 3 & 2.3 & 0 & 0.0 & 0 & 0.0 \\
\hline Total & 8 & 5.8 & 44 & 30.2 & 63 & 43.0 & 22 & 15.1 & 9 & 6.0 & 0 & 0.0 \\
\hline
\end{tabular}

\subsection{Summary of Results}

The conditions of cats and humans coexistence in selected rural areas in Poland (one of the poorest regions of Poland) significantly differ from the desired.

Only $26 \%$ of cat owners effectively prevent any access of their cats to places for children's fun, $20 \%$ of polled allow their cats to unrestricted access to such places, 54\% allow to partially restricted access.

Majority of those owners who allow their cats to unrestricted or partially restricted access to places for children's fun allow their animals to spend a time out of doors (outside living quarters).

$49.4 \%$ of surveyed allow their cats to unrestricted access to places for food preparation and storage as well as to dining rooms, $10.9 \%$ - only to dining rooms. Majority of them allow their animals to spend a time out of doors (outside living quarters) - that means their cats are not protected from potential exposure to parasites present in the area being outside living quarters (wild animals, other cats and their excrements).

$36 \%$ of surveyed cat owners allow their cats to find their sleeping places inside houses $(24.4 \%$ - in undefined place, $11.6 \%$ in special cat beds). Majority of such cats are allowed to spend a time out of doors, too.

Majority of surveyed $(60.4 \%)$ never bath their cats, $3.4 \%$ bath cats only when they suspect their animals have any parasites. Vast majority of those cats that have never been washed are animals allowed to access to both living areas and open spaces (wild environment).

Deworming prevention and antiparasitic treatment procedures applied to cats living in described rural areas may be considered as unsatisfied. Only $15.1 \%$ of cat owners apply deworming procedures more frequently than once a year. $30.3 \%$ of owners apply antiparasitic compounds only when they are able to see parasites.

Such information suggests that, in described rural region, cats and humans coexistence conditions pose some 
potential risks for parasitic disease transmissions.

\section{Discussion}

5.1 Cats and Humans Coexistence in Europe - Historical and Socio-cultural Conditions. The Differences between Rural and City Areas

Recent studies suggest that cats were domesticated about 10,000 years ago.

Evidence of coexistence between cats and humans dates back to 6000 BCE from the Greek island of Cypress, where archaeologists found bones of cats, humans, and mice buried together (Driscoll et al., 2007).

Ancient Egyptians kept cats mainly to exterminate mice and rats (such rodents caused great losses in the grain storage places). In Ancient Egypt, cats were treated as gods (manifestations of the goddess Bast; this Egyptian goddess had many roles, including the goddess of fertility). There were also laws forbidding the exportation of cats and harm them. The punishment for harming or killing a cat was very harsh.

By the end of the ninth century CE cats have spread throughout Asia and Europe. Such animals were objects of worship, pets and animals kept for rodents' extermination purposes. At that time cats were tolerated or regard with mistrust, but not persecuted.

The situation changed radically with the Christianity spreading. Cats, as other pagan deities (cats - pagan symbol of fertility), were condemned. For many years, cats - especially black ones, considered as the embodiment of the devil, were killed or even tortured before death.

In XII century CE, Europe fell to the plague of rats that came with returning Crusaders. The Church strictly forbade the killing of cats, because only they were able to stop this invasion.

When the danger has passed - the Europeans again began to exterminate cats.

Over the next few centuries, the cat was an animal treated with contempt, especially among the urban population. Over time, such animals were back in grace: the cats were treated as mascots for the ladies. Gradually, people began to tolerate them in rural households, too.

Practical considerations, and therefore the presence of rodents and the need to protect stores grain against mice and rats, meant that the cats still have a role in the economic life of the villages. Cats are still the cheapest means for killing rodents. Thus, there can be noticed a large number of cats in the countryside and the freedom of their movement over open areas.

In cities, the presence of rodents posed fewer problems. Moreover zoophobia which came after Pasteur reports (nineteenth century CE) on the possible role of animals in the spread of disease was much stronger in urban than in rural areas.

Above conditions, and many superstition related to cats make that the number of such animals in the cities is much smaller than in rural areas. In addition, cats in the cities are usually are kept as pets, that means that the freedom of movement of such animals is restricted.

So cats reared in cities pose a lower epidemiological risk than those living in rural areas.

\subsection{The Possible Causes of Cats and Humans Coexistence Conditions Improprieties}

The results of study suggest the presence of many crucial problems concerning the conditions of cats and humans coexistence in rural areas.

These improprieties relate to hygiene and sanitary conditions of the presence of cats in homes, their contacts with children, places of preparation and storage of meals, access to dining-rooms, as well as to sanitary-hygiene procedures and vaccination applied to cats living or temporarily stay in house environment.

The described above improper cats and humans relationships may be conditioned by historical reasons, educational negligence, inadequate veterinary care, as well as in economic circumstances.

\subsubsection{Educational Negligence - Important Risk Factor for Transmission of Parasites}

Until the second half of 20th century, rural regions in Poland, like many rural regions in Europe, were evidently culturally and educationally neglected. The situation has evidently changed during the last 30 years, but even now people living in the countryside are statistically less educated than those in cities. Farmers in Poland are the worst educated group of professionals. The aspirations of rural youth are much lower than that living in cities. Many families have not financial possibilities to send children to colleges. The direct communication links in rural areas as well as the access to a broader education, libraries or broadband Internet connections are still insufficient (Pilch, 2002; Kamiński \& Knieć, 2012). 
These factors favour the preservation of old habits, the survival of old traditions and superstitions as well as hinder the appearance of new habits related to modern hygiene and health promotion (Bereszyński \& Tomaszewska, 2006; Słońska, 2000; Gniazdowski, 1990).

The presented above data (table 1) suggesting that majority of surveyed country dwellers allow their cats both to move over open areas and to unlimited as well as unsupervised access to places of children's fun and recreation, to places for preparing, storage of food as well and to dining rooms, may suggest or intentional exposure human health to danger (which seems unlikely) or lack of knowledge due to insufficient health education - which is very probable.

\subsubsection{Veterinary Care System in Polish Rural Regions - Possible Impact on Health Status of Animals}

In rural regions of Lubelskie province, only $15.1 \%$ of cat owners (Table 5) realize deworming procedures more frequently than once a year $(84.9 \%$ - less frequently), people decide to risky animal - human contacts (cats with no free move restrictions are allowed to unsupervised contacts with children and food) and lots of them don't bother about animal hygiene (tables 1-4). Such list of irregularities should cause major concern. Among the reasons there may be improper veterinarians - cat owners co-operation (including educational negligence) or financial troubles. Such problem seems to be worthy of further investigations.

There are opinions that suggest that in rural areas, general practitioners and veterinarians should be obligated to supervise and organize activities in the field of parasitic diseases prophylaxis. Although physicians could play a role in educating patients, studies indicate that their involvement in such types of actions is less evident than involvement of veterinarians. So the veterinary doctors may be considered as one of the most important elements of animal hygiene education and keeping proper standards of hygiene and deworming procedures. But there are problems because of the fact that many veterinarians - all over the world - do not actively educate clients on the zoonotic risk of parasites, despite even significant zoonotic risks. In Western Canada, in 2007, almost 46\% of responding veterinarians confessed negligence in active educate clients on the zoonotic risk of small animal-derived endoparasites. In 2007, in King County (Washington, USA), only $43 \%$ of veterinarians reported that they had initiated discussions about zoonotic diseases with clients on a daily basis (Lipton, Hopkins, Koehler, \& DiGiacomo, 2008).

Veterinary care system in Poland is based on paid prevention and treatment realized by veterinary centers and private veterinary practitioners. Animal health insurance system in Poland is not popular nowadays; it concerns the few wealthy owners of the animals. Voluntary insurances are more popular among big animal farm or purebred livestock owners or among rich few pet owners - mainly citizens. Poor farmers with incomes below the poverty line, economize on expenses. Among others, forgoing veterinary care - especially in the cases of small and less worthy animals - is one of possible ways of reducing costs.

Such opinion was emphasized by Kołłątaj and co-authors (Kołłątaj et al., 2012) who described lack of veterinary certificates in almost $50 \%$ of dog owners and widespread practice involving economizing on veterinary care over dogs living in farms in rural areas of Bełżyce, Chodel, Opole Lubelskie and Poniatowa districts in Lublin province (lack of veterinary certificates means no confirmed contacts veterinary doctors - animal owners).

Thus lots of cat owners don't bother about contacts with local veterinary services and - on the other hand veterinarians don't take initiative in educating and in looking for owners possessing animals being in need of dewormings and don't offer consulting services. Such status quo of educational and veterinary negligence causes the continued presence of endemic foci of parasitic infections, increases risk of parasitic diseases spreading and influences on the health status of local populations.

\subsubsection{Cat Hygiene Negligence - Important Risk Factor for Transmission of Parasites}

The behaviour of people has a pivotal role to play in the macro and microepidemiology of emerging or re-emerging parasitic zoonoses (Macpherson, 2005). In Europe, farming and pet ownership have been identified as important risk factors of spreading such diseases. Improving both personal and animal hygiene are the crucial factors affecting the significant reduction in the risk of spreading zoonoses. It should be good to know the best rules of hygiene and consistently apply them.

Despite what many popularly believe, cats cannot truly keep themselves clean by licking. Cats' fur may contain not only fleas, ticks and mites but also Toxocara eggs (Overgaauw et al., 2009), Giardia cysts, tapeworm segments (stuck to the hair around the cat's anus) and others. Cats can benefit from regular bathing because it helps remove dead hair and skin that accumulates as well as excess oils. They don't like water - that is a well-known fact. However, any cat can be trained to tolerate a bath. There are not settled detailed recommendations for bathing cats both in Poland and other developed countries. The suggestions are as follows: 
bathing cat is something that is not absolutely necessary to do on a weekly basis but a monthly basis is recommended just to make sure that cat is clean (Sly Cat Care Guru, 2012); the Persian and Persian-related cats may need to be bathed every month or two to keep the long coat clean; hunting cats being allowed to stay in living quarters should be bathed more frequently than those being only pets; cats possessed by owners suffering from allergy to cats' fur containing allergen called $\mathrm{Fel} d 1$ should be bathed even 1-2 times a week (Avner, Perzanowski, Platts-Mills, \& Woodfolk, 1997). The problem is that the term "bathing cats" means the hygienic procedure that requires usage of not a pure water and a simple soap or a people shampoo but special cat-specific cosmetics - products formulated specifically for cats. Such cosmetics make even frequent bathing safe for cat's fur and skin ( $\mathrm{pH}$ balanced for cat's skin, hypoallergic, gentle and non-irritating).

Theoretically, the fact that $60.5 \%$ of polled cat owners declared no bathing cats (option "never" - Table 4) may be an effect of: educational backwardness, the lack of any clearly defined recommendations, the fact that availability of such preparations in rural areas is difficult, the lack of proper cooperation between cat owners and veterinarians, financial reasons (the cost of special cosmetics for cats is higher than the cost of a bar of soap or people shampoo) or combination of mentioned reasons. Such problem seems to be worthy of further investigations.

\subsubsection{Economic Realities of Rural Life and Financial Aspects of Deworming Programs}

As was explained by historical sources, all over the world, living conditions in rural areas caused many problems with the maintenance of personal hygiene and health care.

Such types of comments apply also to rural areas in Poland. Among the reasons there are financial problems (Polish rural inhabitants have always been poor), cultural and civilization-related delays. These problems have been particularly evident in areas of the former Austro-Hungarian and Russian annexations, and the consequences are still present in such provinces as Lubelskie province (Brandmüller (Ed.), 2011).

Poverty may be one of the most important reasons for deworming negligence. Polled cat owners were inhabitants of one of the poorest part of our country where in 2008 there were noticed the highest proportions of families living in poverty (in Lublin Province the percentage of unemployed was equal to 15.3, while in Poland its' average value was close to 10.6 (Zgierska, 2009). In 2009 average monthly income per one person in the Lublin Province was equal to 826 PLN (currency - Polish Zloty; 1 PLN = 0.3 USD) (Zgierska, 2009a), while average monthly income in Poland was almost 35\% higher and amounted to 1114.49 PLN (Główny Urząd Statystyczny [GUS], 2010; Zgierska, 2009a).

Lubelskie province still remains one of the poorest part of the country. The majority of the rural areas are dominated by the agricultural function. The level of development of agriculture there is very low, so profit ability of agricultural production is low, and farmers' incomes are very low, too.

Such financial status is associated with the needs for drastic savings. Lack of money force farmers to make savings on purchases of special beds for animals, special hygiene measures as well as on deworming procedures and on veterinary care. These decisions result in failure to care for hygiene and health. In the absence of financial resources, health and living conditions of animals are swept into the background.

In our country, the deworming procedures require veterinary consultations and use drugs that may be available only on prescription. The typical deworming procedure needs spending no less than 15-25 PLN (costs of both: deworming drug and veterinary consult). Such price does not include the cost of any laboratory tests for parasites. It must be added that one can also find antiparasitic medications at a price exceeding 30-40 PLN.

The frequency of dewormings depends on lifestyle of a cat. It is recommended twice yearly deworming as a minimum and deworming at intervals of three months for any cat that hunts regularly (Companion Animal Parasite Council, 2011). The costs of such procedures may pose financial problems especially for many country dwellers that declare lack of financial reserves (Kołłątaj, Kołłątaj, Karwat, \& Piecewicz-Szczęsna, 2010) and possess greater numbers of cats or both cats and dogs.

On this background, the results of the study (Table 5) suggesting that only $15.1 \%$ of cat owners apply deworming procedures more frequently than once a year and $30.3 \%$ of owners apply antiparasitic compounds only when they are able to see parasites must be considered as possible negligence raising from (first of all) economic or both economic and educational reasons. Such problem seems to be worthy of further investigations.

\subsection{Possible Practical Significance of Assessing the Humans and Animals Coexistence Irregularities}

The described above irregularities - in the theory - would be the threat to health of people living in rural areas. If the threat is real, the number of registered zoonotic diseases should be higher than in cities, where the number of 
kept cats is less, the freedom movement of such animals limited and hygienic conditions are better.

The statistics do not raise doubts as to the fact that zoonotic parasitic diseases are more common among rural residents than among citizens. This also applies to diseases such as toxoplasmosis, toxocariasis - that is, diseases that may transmitted by cats, not only by dogs (Jarosz, Andrzejewska, Rychlicki, \& Mizgajska-Wiktor, 2007; Gawor et al., 2008; Sroka et al., 2010).

Such data should motivate decision makers to take effective actions to eliminate irregularities and, consequently, reduce risks and improve the epidemiological status of rural areas.

\section{Conclusions}

In rural areas, hygiene and veterinary cats care negligence as well as animal-human coexistence conditions may increase the risk of zoonotic parasite diseases spreading. Nowadays, veterinary practices and media have the important responsibility of educating cat owners about the potential risk of zoonotic parasitoses.

\section{References}

Amen, O. M. (2001). Neuro-cutaneous Syndrome (NCS); a new disorder. Explore, 10, 55-56.

Avner, D. B., Perzanowski, M. S., Platts-Mills, T. A., \& Woodfolk, J. A. (1997). Evaluation of different techniques for washing cats: quantitation of allergen removed from the cat and the effect on airborne Fel $\mathrm{d} 1$. J Allergy Clin Immunol, 100, 307-312. http://dx.doi.org/10.1016/S0091-6749(97)70242-2

Barsoum, R. S. (2007). Parasitic infections in organ transplantation. Exp Clin Transplant, 2, 258-267.

Bojar, I., \& Szymańska, J. (2010). Environmental exposure of pregnant women to infection with Toxoplasma gondii - state of the art. AAEM, 17, 209-214.

Bereszyński, A., \& Tomaszewska, S. (2006). Zwierzęta a zabobony. Poznań: Wydawnictwo Akademii Rolniczej.

Brandmüller, T. (Ed.). (2011). Eurostat regional yearbook 2011. Luxembourg: Publications Office of the European Union.

Büyükbaba Boral, O., Uysal, H., Alan, S., \& Nazlican O. (2004). Investigation of intestinal parasites in AIDS patients. (Article in Turkish). Mikrobiyol Bul, 38, 121-128.

Companion Animal Parasite Council. (2011). CAPC Recommendations for Parasites. Received from: http://www.capcvet.org/recommendations/guidelines.html

Driscoll, C. A., Menotti-Raymond, M., Roca, A. L., Hupe, K., Johnson, W. E., Geffen, E., ... Macdonald, D. (2007). The Near Eastern Origin of Cat Domestication. Science, 317(5837), 519-523. http://dx.doi.org/10.1126/science.1139518

Gawor, J., Borecka, A., Dobosz, S., Marczyńska, M., Żarnowska-Prymek, H., Trzebicka, A., \& Jadwiga, J. (2008). Toksokaroza u dzieci - trudny problem kliniczny. Przeglad Epidemiol, 62, 407-413.

Główny Urząd Statystyczny. (2010). Gospodarstwa domowe dochody i wydatki w 2009 roku. Lublin, Urząd Statystyczny w Lublinie.

Główny Urząd Statystyczny. (2011). Województwo Lubelskie. Podregiony, powiaty, gminy 2011. Lublin, Urząd Statystyczny w Lublinie.

Gniazdowski, A. (1990). Zachowania zdrowotne. Zagadnienia teoretyczne, próba charakterystyki zachowań zdrowotnych społeczeństwa polskiego. Łódź: Instytut Mededycyny Pracy.

Grant, S., \& Olsen, C. W. (1999). Preventing zoonotic diseases in immunocompromised persons: The role of physicians and veterinarians. Emerg Infect Dis, 5, 159-163. http://dx.doi.org/10.3201/eid0501.990121

Guillot, J., \& Bouree, P. (2007). Zoonotic worms from carnivorous pets: risk assessment and prevention. (Article in French). Bull Acad Natl Med, 191(1), 67-78.

Jarosz, W., Andrzejewska, I., Rychlicki, W., \& Mizgajska-Wiktor, H. (2007). The comparison of learning achievements of rural children seropositive and seronegative for toxocarosis and toxoplasmosis. Wiad. Parazyt., 53 (supl.), 117.

Kamiński, R., \& Knieć, W. (2012). Problemy polskiej wsi w kontekście informatyzacji. Metoda e-VITA. Received from: http://www.witrynawiejska.org.pl/data/mevita/content/evita2.pdf

Kołłątaj, W., Niewiadomy, St., \& Szewczyk, L. (2001). Nierówność źrenic, jako objaw wiodący w skąpoobjawowej toksokarozie u 11 letniego chłopca. Przegl Pediatr, 2, 144-147. 
Kołłątaj, W., Kołłątaj, B., Karwat, I. D., \& Piecewicz-Szczęsna, H. (2010). Wpływ czynników ekonomicznych na możliwości ambulatoryjnej wielolekowej terapii chorób przewlekłych. In Międzynarodowa Konferencja Naukowa III Rzeszowskie Dni Pielęgniarstwa. Zdrowie publiczne a pielęgniarstwo XXI wiekuRzeszów, 3-4 grudnia 2010, pp. 55-56. Rzeszów.

Kołłątaj, W., Milczak, A., Kołłątaj, B., Karwat, I. D., Sygit, M., \& Sygit, K. (2012). Risk factors for the spread of parasitic zoonoses among dog owners and their families in rural areas. AAEM, 19(1), 63-68.

Lipton, B. A., Hopkins, S. G., Koehler, J. E., \& DiGiacomo, R. F. (2008). A survey of veterinarian involvement in zoonotic dis-ease prevention practices. $J$ Am Vet Med Assoc, 233, 1242-1249. http://dx.doi.org/10.2460/javma.233.8.1242

Macpherson, C. N. L. (2005). Human behaviour and the epidemiology of parasitic zoonoses. Int J Parasitol, 35, 1319-1331. http://dx.doi.org/10.1016/j.ijpara.2005.06.004

Niedworok, M., \& Płaneta-Małecka, I. (2004). Clinical course of toxocarosis in children. Wiad Parazytol, 50(3), 461-464.

Overgaauw, P. A., van Zutphen, L., Hoek, D., Yaya, F. O., Roelfsema, J., Pinelli, E., ... Kortbeek, L. M. (2009). Zoonotic parasites in fecal samples and fur from dogs and cats in The Netherlands. Vet Parasitol, 163, 115-122. http://dx.doi.org/10.1016/j.vetpar.2009.03.044

Pilch, T. (2002). Równość szans edukacyjnych w kontekście warunków społecznych i regulacji reformy oświaty. In D. Waloszek \& K. Węża (Eds), Nadzieja na zmianę. Szanse edukacyjne modego pokolenia ze środowiska wiejskiego. Zielona Góra: Ośrodek Doskonalenia Nauczycieli.

Randolph, S. E. (2001). The shifting landscape of tick-borne zoonoses: tick-borne encephalitis and Lyme borreliosis in Europe. Philos Trans $R$ Soc Lond B Biol Sci, 356, 1045-1056. http://dx.doi.org/10.1098/rstb.2001.0893

Schantz, P. M. (2003). Zoonotic ascarids and hookworms: The role for veterinarians in preventing human disease. Compend Contin Educ Pract Vet, 24, 47-52.

Sly Cat Care Guru. (2012). Tips on bathing your cat. Received from: http://petcareeducation.com/cat/tips-on-bathing-your-cat/

Słońska, Z. (2000). Promocja zdrowia w Polsce. Rozwiązania systemowe a rzeczywistość. Promocja Zdrowia. Nauki Społeczne i Medycyna, 19, 34-45.

Smith, P. D., Lane, H. C., Gill, V. J., Manischewitz, J. F., Quinnan, G. V., Fauci, A. S., \& Masur, H. (1998). Intestinal infections in patients with the Acquired Immunodeficiency Syndrome (AIDS). Etiology and response to therapy. Ann Intern Med, 108, 328-333.

Sroka, J., Wójcik-Fatla, A., Szymańska, J., Dutkiewicz, J, Zając, V., \& Zwoliński, J. (2010). The occurrence of Toxoplasma gondii infection in people and animals from rural environment of Lublin region-estimate of potential role of water as a source of infection. AAEM, 17, 125-132.

Stojčević, D., Sušić, V., \& Lučinger, S. (2010). Contamination of soil and sand with parasite elements as a risk factor for hu-man health in public parks and playgrounds in Pula. Croatia Vet Arhiv, 80, 733-742.

Stull, J. W., Carr, A. P., Chomel, B. B., Berghaus, R. D., \& Hird, D. W. (2007). Small animal deworming protocols, client education, and veterinarian perception of zoonotic parasites in western Canada. Can Vet J, 48(3), 269-276.

Valar, C., Keitel, E., Dal Prá, R. L., Gnatta, D., Santos, A. F., \& Bianco, P. D. (2007). Parasitic infection in renal transplant recipients. Transplant Proc, 39, 460-462. http://dx.doi.org/10.1016/j.transproceed.2007.01.025

Wolfe, A., \& Wright, I. P. (2003). Human toxocariasis and direct contact with dogs. Vet Rec, 152, 419-422. http://dx.doi.org/10.1136/vr.152.14.419

Zgierska, A. (2009). Measurement of material poverty range in Poland in 2008 with the use of various poverty lines. In A. Zgierska (Ed.). Household budget surveys in 2008 (pp. 54-56). Warszawa: ZWS.

Zgierska, A. (2009a). The situation of households in 2008 based on the household budget surveys. In A. Zgierska (Ed.). Household budget surveys in 2008, pp. 37-53. Warszawa: ZWS. 